\title{
THE CORRELATION OF MOTHER'S KNOWLEDGE AND ATTITUDE WITH BREASTFEEDING PRACTICES IN TULANG BAWANG BARAT DISTRICT AT 2021
}

\author{
Anik Yulianty $^{1 *}$, Sugeng Eko Irianto $^{2}$, Ai Kustiani $^{3}$ \\ 1. Masters Program in Public Health, Mitra Indonesia University, Lampung-Indonesia \\ 2. Masters Program in Public Health, Mitra Indonesia University, Lampung-Indonesia \\ 3. Masters Program in Public Health, Mitra Indonesia University, Lampung-Indonesia
}

*Correspondence: Anik Yulianty | Mitra Indonesia University | anikyulianty888@ gmail.com

\begin{abstract}
Introduction:Breast milk is a liquid formed from a mixture of two substances, namely fat and water contained in a solution of protein, lactose and inorganic salts produced by the mother's breast glands, and is useful as baby food. Mother's knowledge and attitude in exclusive breastfeeding plays an important role in increasing the growth and development of children. The purpose of this study was to determine the relationship between the level of knowledge (cognitive factors) and attitudes (affective factors) of mothers in the practice of exclusive breastfeeding in Tulang Bawang Barat District in 2021.

Method: This research is a quantitative research, with a cross sectional approach. The population in this study were all mothers who had babies > 6 months- 12 months as many as 2285 with samples taken as many as 93 respondents. The object of this research is exclusive breastfeeding, knowledge and attitude. The research was conducted in June 2021 in the District of Tulang Bawang Barat. Collecting data using a questionnaire, data analysis is univariate, bivariate and multivariate.

Results: The results showed that there was a relationship between knowledge ( $\mathrm{p}$ value $=0.016, \mathrm{OR}=3.264$ ), and attitudes ( $\mathrm{p}$ value $=0.001, \mathrm{OR}=7.848$ ) towards exclusive breastfeeding in Tulang Bawang Barat District in 2021 . Dominant factors related to exclusive breastfeeding in Tulang Bawang Barat District in 2021, namely the attitude with a p-value of 0.000 OR 10.197 .

Conclusion: The dominant factor related to the practice of exclusive breastfeeding in Tulang Bawang Barat is the attitude of the mother. To improve the attitude of mothers in the Practice of Exclusive Breastfeeding, the Health Office needs to carry out health promotions with a more frequent frequency by using more attractive health promotion media in collaboration with the health promoter team at the puskesmas.
\end{abstract}

Keywords: Attitude, Dominant factor, Exclusive breastfeeding, Knowledge.

Received December 1, 2021; Accepted December 30, 2021

\section{INTRODUCTION}

Exclusive breastfeeding only includes breastfeeding the baby and does not include any other food or drink, including water, other than medicines and vitamin or mineral drops; Expressed breast milk is also allowed from birth until the baby is 6 months old (Rahman, 2017).

According to $\mathrm{WHO}$, the proportion of exclusive breastfeeding worldwide is $43 \%$. This result is still below 50\% of the global target of the World Health Assembly (WHA) (Bakri, 2018). The rate of exclusive breastfeeding in Indonesia is very low, only $74.5 \%$ of the $80 \%$ target (Balitbangkes, 2019). In Lampung Province, the proportion of infants who were exclusively breastfed in 2019 was $69.3 \%$, still below the expected target of $80 \%$ (Lampung Health Profile, 2019). In the Tulang Bawang Barat region, the rate of exclusive breastfeeding for infants aged 6 months in 2017 was $51.5 \%$ and the expected target was 83\%.(Health Profile of Tulang Bawang Barat District, 2017). Many health programs in Tulang Bawang Barat District support exclusive breastfeeding activities. These activities include the Breastfeeding Program, Lactation Support Group, and Mother Toddler Program. However, the rate of exclusive breastfeeding in Tulang Bawang Barat District is still low.

Babies who do not get exclusive breastfeeding can have a negative impact on their health. Infants who are exclusively breastfed are 3.94 times more likely to die from diarrhea (Ministry of Health, 2010). Babies who are not fully breastfed are also at a higher risk of stunting. Among infants aged 624 months who were 
not fully breastfed, $30.7 \%$ had a higher rate of developmental delay than exclusively breastfed infants under 5 years of age, and only $11.1 \%$ had developmental delays (Devriany, 2018) .

To increase the prevalence of exclusive breastfeeding nationally, the government has issued regulations to protect children's rights to breastfeed, such as Health Law no. 36 of 2009 and Government Regulation No. 33 (PP) of 2012 which regulates exclusive breastfeeding. Regarding breastfeeding facilities in the workplace, the government issued Regulation of the Minister of Health of the Republic of Indonesia Number 15 of 2013 concerning Procedures for Providing Special Facilities for Breastfeeding and/or Dairy which is also an order for execution of the Health Law.

The data above shows that although the government has tried various programs to gain public sympathy to participate in the exclusive breastfeeding program, the community has not fully realized the importance of exclusive breastfeeding. In several developed and developing countries, including Indonesia, many mothers do not give exclusive breastfeeding. Exclusive breastfeeding may become more popular as mothers' knowledge and attitudes increase. Mother's knowledge and attitudes towards effective exclusive breastfeeding must be carried out throughout the process from pregnancy to breastfeeding, the effect will be better if accompanied by close relatives or counselors.

According to L. Green's behavioral view, one of the factors that influence a person's healthy behavior is one's knowledge and attitude. Knowledge and attitude are very important fields that determine behavior. Behavior based on knowledge, awareness and positive attitude will be more sustainable. Good knowledge makes it easier for people to change their behavior, including breastfeeding practices (Septiani, 2017). So researchers are interested in conducting research on the Relationship of Mother's Knowledge and Attitudes with Exclusive Breastfeeding Practices in Tulang Bawang Barat District in 2021.

\section{METHOD}

The type of research used in this research is quantitative research. This study adopted a cross sectional research design. The measuring instrument used in this research is in the form of a questionnaire, the data obtained in the form of interviews from respondents to the questions or items proposed. Mother's level of knowledge and attitude are independent variables while the dependent variable is exclusive breastfeeding. The place that the researcher will use in this research is in the Tulang Bawang Barat District on June 2 June 30, 2021.

The study population was all mothers who had babies $>6$ months- 12 months in the district of Tulang Bawang Barat. The total population in the Tulang Bawang Barat District, based on projected data from April 2021, mothers who have babies aged > 6 months-12 months amounted to 2285. In this study, the researchers took a sampling technique using a combination of two sampling techniques, namely cluster sampling and proportional random sampling. The sample size to be taken is 93 respondents.

\section{RESULTS}

The results of the study on 93 mothers who had babies aged > 6 months-12 months in Tulang Bawang Barat District, the results were presented in the form of a table as follows:

Table 1. Distribution of the frequency of maternal knowledge with exclusive breastfeeding practices in Tulang Bawang Barat District in 2021

\begin{tabular}{ccc}
\hline Variable & Frequency & Percentage (\%) \\
\hline Good & 49 & 52.7 \\
Not good & 44 & 47.3 \\
\hline Total & 93 & 100.0 \\
\hline
\end{tabular}

It is known that from 93 respondents, some of the respondents with good knowledge were 49 (52.7\%) and $44(47.3 \%)$ respondents with poor knowledge.

Table 2. Frequency distribution of mothers' attitudes with exclusive breastfeeding practices in Tulang Bawang Barat District in 2021

\begin{tabular}{lll}
\hline Variable & Frequency & Percentage $(\%)$ \\
\hline
\end{tabular}




\begin{tabular}{ccc}
\hline Good & 50 & 53.8 \\
Not good & 43 & 46.2 \\
\hline Total & 93 & 100.0 \\
\hline
\end{tabular}

It is known that out of 93 respondents, most of them respondents with a good attitude were 50 (53.8) andrespondents with unfavorable attitude as much as 43 (46.2\%).

Table 3. Distribution of the frequency of exclusive breastfeeding in Tulang Bawang Barat District in 2021

\begin{tabular}{ccc}
\hline Variable & Frequency & Percentage (\%) \\
\hline Exclusive breastfeeding & 34 & 36.6 \\
Not Exclusive & 59 & 63.4 \\
\hline Total & 93 & 100.0 \\
\hline
\end{tabular}

It is known that out of 93 respondents, most of them respondents with exclusive breastfeeding were 34 (36.6\%) and respondents with non-exclusive as many as 59 (63.4\%).

Table 4. The relationship between mother's knowledge on the practice of exclusive breastfeeding in the Tulang Bawang Barat District in 2021

\begin{tabular}{|c|c|c|c|c|c|c|c|c|}
\hline \multirow{3}{*}{ Knowledge } & \multicolumn{4}{|c|}{ Breastfeeding } & \multirow{3}{*}{$\mathbf{N}$} & \multirow{3}{*}{$\%$} & \multirow{3}{*}{$p$-value } & \multirow{3}{*}{$\begin{array}{c}\text { OR } \\
95 \% \mathrm{CI}\end{array}$} \\
\hline & \multicolumn{2}{|c|}{ exclusive breastfeeding } & \multicolumn{2}{|c|}{ Not Exclusive } & & & & \\
\hline & $\mathbf{N}$ & $\%$ & $\mathbf{N}$ & $\%$ & & & & \\
\hline Good & 24 & 49.0 & 25 & 51.0 & 49 & 100.0 & \multirow{3}{*}{0.016} & \multirow{3}{*}{$\begin{array}{c}3,264(1,326- \\
8,032)\end{array}$} \\
\hline Not good & 10 & 22.7 & 34 & 77.3 & 44 & 100.0 & & \\
\hline Total & 34 & 36.6 & 59 & 63.4 & 93 & 100.0 & & \\
\hline
\end{tabular}

It is known that from 49 respondents with good knowledge, as many as $24(49.0 \%)$ respondents with exclusive breastfeeding and as many as $25(51.0 \%)$ of respondents with non-exclusiveness. From 44 respondents with poor maternal knowledge, as many as 10 (22.7\%) respondents with exclusive breastfeeding and as many as $34(77.3 \%)$ respondents with not exclusive breastfeeding. Statistical test results obtained $\mathrm{p}$-value $=00.016$ which means $\mathrm{p}<\alpha=0.05$ (Ha is accepted and Ho is rejected), it can be concluded that there is a knowledge relationship mothers on the practice of exclusive breastfeeding in Tulang Bawang Barat District in 2021, with an OR value of 3,264 means that respondents with poor knowledge have a 3,264 chance times greater for not being given exclusive breastfeeding when compared to respondents with good knowledge.

Table 5. Presentation of Mother's Knowledge Level with Knowledge Levels C1, C2, and C3

\begin{tabular}{cc}
\hline Knowledge Level & Percentage (\%) \\
\hline C1 & 70,96 \\
C2 & 68,81 \\
C3 & 49,19 \\
\hline
\end{tabular}

Based on the table above, it can be seen that not all mothers can fill out the questionnaire correctly at the level of application (C3). The mother's ability at the level of application (C3) in answering the knowledge questionnaire has the lowest percentage, namely $49.19 \%$ and can be categorized into less predicate.

Table 6. The relationship between mother's attitude towards the practice of exclusive breastfeeding in the Tulang Bawang Barat District in 2021 


\begin{tabular}{|c|c|c|c|c|c|c|c|c|}
\hline \multirow{3}{*}{ Attitude } & \multicolumn{4}{|c|}{ Breastfeeding } & \multirow{3}{*}{$\mathbf{n}$} & \multirow{3}{*}{$\%$} & \multirow{3}{*}{ p-value } & \multirow{3}{*}{$\begin{array}{c}\text { OR } \\
95 \% \mathrm{CI}\end{array}$} \\
\hline & \multicolumn{2}{|c|}{ breast milk exclusive } & \multicolumn{2}{|c|}{ Not Exclusive } & & & & \\
\hline & $\mathbf{n}$ & $\%$ & $\mathbf{n}$ & $\%$ & & & & \\
\hline Good & 28 & 56.0 & 22 & 44.0 & 50 & 100.0 & & 784802809 \\
\hline Not good & 6 & 14.0 & 37 & 86.0 & 43 & 100.0 & 0.001 & $2193)$ \\
\hline Total & 34 & 36.6 & 59 & 63.4 & 93 & 100.0 & & \\
\hline
\end{tabular}

Based on the table above, it can be seen that from 50 respondents with good attitudes, 28 (56.0\%) respondents were given exclusive breastfeeding and as many as $22(44.0 \%)$ respondents were not given exclusive breastfeeding. of 43 respondents with unfavorable attitudes, as many as $6(14.0 \%)$ respondents were given exclusive breastfeeding and $37(86.0 \%)$ respondents were not given exclusive breastfeeding. The results of statistical tests obtained $p$-value $=0.001$ which means $p$-value $<\alpha(0.05)$, it can be concluded that there is a relationship between mothers' attitudes towards the practice of exclusive breastfeeding in Tulang Bawang Barat District in 2021. With an OR value of 7.848, it means that respondents with a bad attitude has a risk of 7.848 times greater not being given exclusive breastfeeding when compared to respondents with a good attitude.

Table 7. Percentage of Mothers' Attitude Levels with Levels A1, A2, A3, and A4

\begin{tabular}{cc}
\hline Attitude Level & Percentage (\%) \\
\hline A1 & 81,72 \\
A2 & 61,64 \\
A3 & 60,93 \\
A4 & 54,83 \\
\hline
\end{tabular}

Based on the table above, it can be seen that not all mothers can fill out the questionnaire correctly at the organizational level (A4). The ability of the mother at the attitude level (A4) in answering the questionnaire. The mother's attitude had the lowest percentage, namely $54.83 \%$ and could be categorized into the predicate less.

Table 8. Multivariate Analysis Complete model of potential covariates

\begin{tabular}{ccccc}
\hline \multirow{2}{*}{ Variable } & \multirow{2}{*}{ Sig. } & \multirow{2}{*}{$\operatorname{Exp}(\mathbf{B})$} & \multicolumn{2}{c}{ 95\% CIfor $\operatorname{EXP}(\mathbf{B})$} \\
& & & Lower & Upper \\
\hline Knowledge & 0.004 & 4,686 & 1,638 & 13,405 \\
Attitude & 0.001 & 10,197 & 3,328 & 31,239 \\
\hline
\end{tabular}

Based on the table above, the stage I multivariate model turns out to be the variable that has the highest $\mathrm{p}$-value $<0.05$, namely the attitude variable $(\mathrm{p}=0.001)$ and knowledge, but attitude has the highest $\exp (\mathrm{B})$ value of 10.197. So the attitude variable is the dominant variable related to the practice of exclusive breastfeeding.

\section{DISCUSSION}

Knowledge is the simplest behavior in the order of cognitive behavior. A person can gain knowledge from new and accessible facts or information. It also provides insight from life experiences that can influence a person's behavior when learning important information (Potter \& Perry, 2009).

A person's information and experiences about exclusive breastfeeding can influence their exclusive breastfeeding behavior. Knowledgeable mothers are 5.47 times more likely to give exclusive breastfeeding than knowledgeable mothers (Pertiwi, 2012).

A mother who has never received advice or experience about breastfeeding and its details from others or from reading books can influence her attitude towards breastfeeding. A person's attitude is influenced by the knowledge they have, if the relevant knowledge is lacking, they will have a negative attitude towards breastfeeding (Hartatik, 2009).

Sjawie (2019) said that there was a relationship between knowledge and attitudes towards exclusive 
breastfeeding in the Tumintin Health Center working area, Manado City. The results of univariate data analysis showed that most mothers had low knowledge (66.7\%), mothers with negative attitudes $(69.3 \%)$ and mothers with incomplete breastfeeding (56.0\%). The chi-square test was used to analyze the statistical test of the relationship between variables. The results of the analysis showed knowledge $(p=0.000)$ and attitude ( $\mathrm{p}=0.000)$ of exclusive breastfeeding in the Tuminting Health Center work area.

Septiani, Hanulan (2017) stated that the most important factor related to exclusive breastfeeding is knowledge. Knowledgeable mothers have the opportunity to give exclusive breastfeeding 13 times more than mothers with less knowledge.

Based on the results of research research on the relationship between mother's knowledge of exclusive breastfeeding practices in Tulang Bawang Barat District in 2021, statistical tests obtained p-value $=0.016$ which means $\mathrm{p}<\alpha=0.05$ (Ha is accepted and Ho is rejected), it can be concluded that there is a relationship between mother's knowledge and the practice of exclusive breastfeeding in Tulang Bawang Barat District in 2021, with an OR value of 3.264, meaning that respondents with poor knowledge have a 3.264 times greater chance of not being given exclusive breastfeeding when compared to respondents with good knowledge.

In line with Ilham's research (2015) the results of statistical analysis showed $\mathrm{p}$ value $=0.005$. At Kartasura Health Center there is a significant relationship between mother's knowledge and exclusive breastfeeding. Nurleli's research (2018) shows that mother's knowledge about exclusive breastfeeding is significantly related to exclusive breastfeeding $(\mathrm{p}<0.05)$. Sjawie's research $(2019)$ was used to analyze statistical tests and chi-square tests of the relationship between variables, and the results of the analysis showed knowledge $(\mathrm{p}=0.000)$.

Information and experiences related to exclusive breastfeeding can influence individual behavior during exclusive breastfeeding. Yuliandrin (2009) proved this in his research. Knowledgeable mothers are 5.47 times more likely to give exclusive breastfeeding than knowledgeable mothers (Pertiwi, 2012).

According to L. Green's behavioral concept, one of the factors that influence a person's healthy behavior is one's knowledge and attitude. Knowledge and attitudes are very important fields that determine behavior. Behavior based on knowledge, awareness and positive attitude will be more sustainable. Good knowledge makes it easier for people to change their behavior, including breastfeeding practices (Septiani, 2017).

At the level of application (C3), the mother's ability to answer the knowledge questionnaire has a percentage of $49.19 \%$ and can be categorized into the predicate less. At this level is the lowest percentage. C3 level, application is defined as the ability to use the material that has been studied in actual situations or conditions (Notoatmodjo, 2015). According to the opinion of the researcher, some informants know and understand exclusive breastfeeding, but do not use it in their daily life. There may be other reasons why mothers cannot breastfeed their babies, such as breast milk which prevents mothers from breastfeeding their babies, or other facts not included in this study, for example. continuous promotion of powdered infant milk which seems to describe the development of children, the increasing consumption of infant formula, or mental disorders, such as worrying that breast milk will not firm the breasts. breasts or because of the mother's self-examination, so male support is not available, so health workers provide more information than mothers.

To increase maternal knowledge at the $\mathrm{C} 3$ level, this can be done through health education regarding exclusive breastfeeding. Through health education that is carried out continuously and slowly, mothers will understand the benefits of exclusive breastfeeding and will apply it to their daily lives. So that the knowledge of the C3 level will increase. This is in line with Muninjay's opinion, Health education is to increase one's knowledge and skills through learning skills training or guidance. their behavior. and turn them into healthy behaviors.

Based on the research on the relationship between mothers' attitudes towards the practice of exclusive breastfeeding in Tulang Bawang Barat District in 2021, the results of statistical tests obtained p-value = 0.001 which means $\mathrm{p}$-value $<\alpha(0.05)$, it can be concluded that there is a relationship between mother's attitudes towards the practice of breastfeeding. Exclusive breastfeeding in Tulang Bawang Barat District in 2021. With an OR value of 7.848, it means that respondents with a bad attitude have a 7.848 times greater risk of not being given exclusive breastfeeding when compared to respondents with a good attitude.

In line with Sjawie's research (2019) usechi-square test to analyze the statistical test of the relationship 
between variables, the results of the analysis showed the attitude of the Tuminting Health Center working area towards exclusive breastfeeding $(\mathrm{p}=0.000)$. Wowor's $(2013)$ research on the relationship between attitudes and breastfeeding found $\mathrm{p}=0.036<0.05$ which indicates that there is a relationship between attitudes and breastfeeding. Nurleli's attitude (2018) was also significantly related to exclusive breastfeeding $(\mathrm{p}<0.05)$.

A mother's positive attitude or her consent to exclusive breastfeeding does not necessarily mean that she is exclusively breastfeeding. This is because attitude is a kind of opinion or feeling that produces a tendency to act, but has not yet been transformed into real action.

From the results of the research that the author did, from the four levels of attitude A1 to A4 the lowest percentage was at the level of organizing (A4). At this level, the percentage of correct answers in filling out the A4 questionnaire was $54.83 \%$ with less predicate. The level of attitude to organize or organize (A4) is at this level of attitude that brings together different values, so that new universal values are formed, which lead to general improvement. Organizing or organizing is the development of values from within an organizational system, including the relationship of one value to another, strengthening and prioritizing the values it already has.

Based on the multivariate model stage I, it turns out that the variables that have the highest p-value $<0.05$ are the attitude variable $(\mathrm{p}=0.001)$ and knowledge, but attitude has the highest exp (B) value of 10.197. So the attitude variable is the dominant variable related to the practice of exclusive breastfeeding.

This study shows that the mother's positive attitude to exclusive breastfeeding is a factor that determines a person's willingness or readiness to give exclusive breastfeeding. which is supported by $\mathrm{L}$ Green's theory which states that attitude is a predisposing factor that influences a person's motivation to behave.

Mothers who consider breast milk to be the best food for their babies plan to breastfeed for 6 months. Mother's attitude towards infant feeding is a strong predictor of exclusive breastfeeding. In this context, cooperation with inter-departmental cadres, including local cadres as complementary breastfeeding cadres, is needed to properly monitor and manage exclusive breastfeeding. To encourage mothers to have a positive attitude towards exclusive breastfeeding, village health workers must work closely with the health promotion team of the Puskesmas to continue to actively expand knowledge or provide information to the entire community, especially mothers of children under five.

\section{CONCLUSION}

Based on the results of the study it can be concluded that:

1. The frequency distribution of Mother's Knowledge and Attitude with Exclusive Breastfeeding Practices is as follows:

a. It is known that from 93 respondents, $44(47.3 \%)$ respondents with poor knowledge and $49(52.7 \%)$ respondents with good knowledge.

b. Known that out of 93 respondents, some respondents with $43(46.2 \%)$ unfavorable attitudes and 50 (53.8) good attitude respondents.

c. It is known that out of 93 respondents, some respondents with non-exclusivity were $59(63.4 \%)$ and respondents with exclusive breastfeeding were 34 (36.6\%).

2. There is a relationship between mother's knowledge on the practice of exclusive breastfeeding in Tulang Bawang Barat District in 2021 ( $\mathrm{p}$ value $=0.016$, OR $=3.264$ )

a. The mother's ability at the knowledge level (C1) in answering the knowledge questionnaire has a percentage of $70.96 \%$ and can be categorized into good predicate.

b. The mother's ability at the level of understanding (C2) in answering the knowledge questionnaire has a percentage of $68.81 \%$ and can be categorized into a good predicate.

c. The mother's ability at the level of application (C3) in answering the knowledge questionnaire has a percentage of $49.19 \%$ and can be categorized into the predicate less.

3. There is a relationship between mothers' attitudes towards the practice of exclusive breastfeeding in Tulang Bawang Barat District in 2021 ( $\mathrm{p}$ value $=0.001, \mathrm{OR}=7.848$ ).

a. Mother's attitude at the level of acceptance/receiving (A1) in answering the attitude questionnaire has a percentage of $81.72 \%$ and can be categorized into very good predicate. 

b. The mother's attitude at the level of response/respondent (A2) in answering the attitude questionnaire has a percentage of $61.64 \%$ and can be categorized into the predicate enough.
c. The mother's attitude at the level of valuing (A3) in answering the attitude questionnaire has a percentage of $60.93 \%$ and can be categorized into the predicate enough.
d. The mother's attitude at the organizational level (A4) in answering the attitude questionnaire has a percentage of $54.83 \%$ and can be categorized into less predicate.

4. It is known that the dominant factor of attitude is related to exclusive breastfeeding in Tulang Bawang Barat District in 2021 ( $\mathrm{p}$ value $=0.000, \mathrm{OR}=10.197$ ).

\section{REFERENCE}

Devriany, A. 2018. Perbedaan Status Pemberian ASI Eksklusif terhadap Perubahan Panjang Badan Bayi Neonatus. Pangkalpinang.

Hartatik, T. 2009. Hubungan Pengetahuan Dan Sikap ibu Dengan Pemberian Asi Eksklusif Dikelurahan Gunungpati Kecamatangunungpati Kota Semarang Tahun 2009. Unnes.

Ilhami, M.F. 2015. Hubungan Tingkat Pengetahuan Ibu Tentang Asi Eksklusif Dengan Tindakan Pemberian Asi Eksklusif Di Puskesmas Kartasura. UMS.

Kemenkes RI. 2010. Riset Kesehatan Dasar (RISKESDAS) 2010. Kemenkes RI, Jakarta.

Pertiwi, P. 2012. Gambaran Faktor-Faktor Yang Mempengaruhi Pemberian ASI Eksklusif Di Kelurahan Kunciran Indah Tangerang. Fakutas Ilmu Keperawatan Universitas Indonesia.

Potter dan Perry. 2009. Fundamental Keperawatan. Edisi 7. Salemba Medika, Jakarta.

Rahman, N. 2017. Pengetahuan, Sikap, Dan Praktik Pemberian Asi Eksklusif Di Wilayah Kerja Puskesmas Jumpandang Baru Kecamatan Tallo Kota Makassar. Universitas Hasanuddin.

Sjawie, W. A. 2019. Hubungan Antara Pengetahuan Dan Sikap Ibu Dengan Pemberian Asi Eksklusif Di Wilayah Kerja Puskesmas Tuminting Kota Manado. Manado.

Septiani S., Budi A., Karbito. 2017. Faktor-Faktor yang Berhubungan dengan Pemberian ASI Eksklusif oleh Ibu Menyusui yang Bekerja sebagai Tenaga Kesehatan. Pascasarjana Kesehatan Masyarakat Stikes Mitra Lampung.

Wowor, M. 2010. Hubungan Pengetahuan Dan Sikap Dengan Pemberian Asi Eksklusif Pada Ibu Menyusui Di Puskesmas Bahu Kota Manado. Manado. 